\title{
Tea Bag Biji Alpukat (Persea Americana Mill) terhadap Kadar Gula Darah Tikus Putih (Rattus Norvegicus)
}

\author{
Yunan Jiwintarum ${ }^{1}$, Ida Eliza ${ }^{2}$, Erlin Yustin Tatontos ${ }^{2}$, Rohmi $^{2}$ \\ Jurusan Analis Kesehatan Politeknik Kesehatan Kemenkes Mataram, Indonesia. \\ email:jiwintarum25@gmail.com
}

\begin{abstract}
ABSTRAK
Latar belakang: Kadar gula darah merupakan faktor yang sangat penting untuk aktivitas tubuh karena gula darah merupakan sumber energi utama yang metabolismenya dihati. Kadar gula darah yang tinggi disebut dengan kondisi hiperglikemik. Keadaan hiperglikemik merupakan gejala penyakit diabetes melitus. Diabetes melitus merupakan masalah yang sering dijumpai di masyarakat Indonesia. Penyakit ini bisa menyebabkan komplikasi mikrovaskuler dan makrovaskuler. Pemberian obat tradisional seperti sediaan biji alpukat ( $P$. americana Mill.) dalam bentuk tea bag diharapkan dapat menurunkan kadar gulah darah. Tujuan : Untuk mengatahui pengaruh sediaan biji alpukat (P. americana Mill.) dalam bentuk tea bag terhadap kadar gula darah tikus putih ( $R$. norvegicus) strain wistar yang hiperglikemik Metode : Penelitian ini merupakan penelitiaan Praeksprimen dengan rancangan penelitian One Group Pretest-Posttes, menggunakan 6 ekor tikus berusia dua sampai empat bulan. Setelah adaptasi selama seminggu dan berhasil diinduksi dengan aloksan, dilakukan pemeriksaan pretest kadar gula darah sewaktu. Perlakuan diberikan selama satu minggu dan dilakukan pemeriksaan kadar glukosa darah posttest. Hasil : Penelitian memperlihatkan rerata kadar gula darah tikus putih strain wistar yang hiperglikemik sebelum diberikan sediaan biji alpukat $(P$. americana Mill.) dalam bentuk tea bag sebesar 226,4 dan rerata setelah diberikan sediaan biji alpukat ( $P$. americana Mill.) dalam bentuk tea bag sebesar $154 \mathrm{mg} / \mathrm{dL}$. Kesimpulan : Sediaan biji alpukat $(P$. americana Mill.) dalam bentuk tea bag memiliki pengaruh terhadap penurunan kadar gula darah tikus putih ( $R$. norvegicus) strain wistar yang hiperglikemik
\end{abstract}

Kata Kunci : Biji Alpukat, Hiperglikemik, Kadar Gula Darah, Tea Bag

\begin{abstract}
Blood sugar levels are a very important factor for body activity because blood sugar is the main energy source whose metabolism is liver. High blood sugar levels are called hyperglycemic conditions. The hyperglycemic state is a symptom of diabetes mellitus. Diabetes mellitus is a problem that is often found in Indonesian society. This disease can cause microvascular and macrovascular complications. Giving traditional medicine such as avocado seeds ( $P$. americana Mill) in the form of tea bag is expected to reduce the level of blood sugar. Objective: To find out the effect of avocado seeds (P. americana Mill.) In the form of tea bag on blood sugar levels of white mice (R. norvegicus) wistar strains that are hyperglycemic Method: This study is a Preexperiment research with a Pretest-One Group research design Posttes, using 6 rats aged two to four months. After a week of adaptation and successfully induced with alloxan, a pretest blood sugar level was tested at the time. The treatment was given for one week and posttest blood glucose levels were examined. Results: The study showed a mean blood sugar level of hyperglycemic wistar white rats before being given avocado seeds ( $P$. americana Mill.) In the form of tea bag 226.4 and average after being given avocado seeds $(P$. americana Mill.) In the form tea bag is 154 mg / dL. Conclusion: Avocado seeds (P. americana Mill) in the form of tea bag have an influence on the decrease in blood sugar levels of white rats ( $R$. norvegicus) hyperglycemic wistar strains
\end{abstract}

Keywords: Avocado Seeds, Hyperglycemic, Blood Sugar Levels, Tea Bag

\section{PENDAHULUAN}

Kadar gula darah darah merupakan faktor yang sangat penting untuk aktivitas tubuh karena gula darah merupakan sumber energi utama yang metabolismenya dihati. Gula darah 
sering disebut dengan glukosa darah. Glukosa merupakan sumber energi utama bagi sel manusia. Glukosa terbentuk dari karbohidrat yang dikonsumsi melalui makanan dan disimpan sebagai glikogen dihati dan otot. Kadar glukosa darah dipengaruhi oleh faktor endogen dan eksogen. Faktor endogen yaitu humoral faktor seperti hormon insulin, glukagon dan kortisol sebagai sistem reseptor di otot dan sel hati. Faktor eksogen antara lain jenis dan jumlah makanan yang dikonsumsi serta aktivitas yang dilakukan. Kadar gula darah yang tinggi disebut dengan kondisi hiperglikemik. Hiperglikemik merupakan salah satu penanda terjadinya kelainan metabolisme karbohidrat, lipid, dan protein. Hiperglikemia adalah suatu keadaan kadar glukosa darah sangat tinggi melebihi kadar normal. Keadaan hiperglikemia merupakan gejala penyakit diabetes melitus (Suarsana, dkk, 2012). Diabetes Melitus adalah suatu sindroma gangguan metabolisme dengan keadaan hiperglikemia berlebihan sebag ai akibat suatu defisiensi sekresi insulin atau berkurangnya efektivitasbiologis dari insulin atau keduanya dengan manifestasi klinis berupa hilangnya toleransi karbohidrat. Poliuria (pengeluaran urine secara berlebihan), polidipsia (minum air secara berlebihan), polifagia (makan secara berlebihan), berkurangnya berat badan dan asthenia (kurangnya energi) merupakan gejala khas pada penyakit diabetes melitus (Anggraeni, 2006). Jumlah penderita diabetes melitus di dunia menurut WDD (World Diabetes Day) 2014 terdapat 382 juta orang yang menderita diabetes melitus tahun 2013, sedangkan negara Indonesia menduduki peringkat ke 5 yang menunjukkan jumlah penderita diabetes melitus terbanyak di dunia. Jumlah populasi penderita berdasarkan data Riset Kesehatan Dasar (Riskesdas) tahun 2013 di Indonesia terdapat 10 juta orang penderita diabetes, dan 17,9 juta orang yang berisiko menderita penyakit ini
(Erawantini, dkk, 2017). Meningkatnya penderita diabetes melitus dari tahun ke tahun memerlukan suatu usaha untuk mengatasinya. Penggunaan obat tradisional menjadi alternatif mengingat obat-obat sintetik memiliki efek samping yang tinggi, seperti kerusakan ginjal, hati, menyebabkan tumor, hipertensi, merusak usus, mengakibatkan kebutaan, menyebabkan kelumpuhan, kejang-kejang, diare, dan sebagainya (Rahman, 2014). Salah satu pengobatan alami yang dapat digunakan adalah tanaman dan buah-buahan, yang salah satunya adalah tanam yang dapat digunakan menurunkan kadar glukosa darah adalah biji alpukat, karena kandungan biji alpukat berupa senyawasenyawa metabolit sekunder dimana yang terdapat pada biji buah alpukat segar dan kering, adalah alkaloid, triterpenoid, tanin, flavonoid, dan saponin (Marlinda, dkk, 2016). Flavonoid inilah yang diduga sebagai agen antidiabetes. Flavonoid adalah senyawa organik alami yang ada pada tumbuhan secara umum. Flavonoid alami banyak memainkan peran penting dalam pencegahan diabetes dan komplikasinya (Iyos, dkk, 2013). Sejumlah studi telah dilakukan untuk menunjukkan efek hiperglikemik dari flavonoid dengan menggunakan model eksperimen yang berbeda, hasilnya tanaman yang mengandung flavonoid telah terbukti memberi efek menguntungkan dalam melawan penyakit diabetes melitus, baik melalui kemampuan mengurangi penyerapan glukosa maupun dengan cara meningkatkan toleransi glukosa (Brahmachari, 2011). Tanin merupakan komponen zat organik yang sangat kompleks, terdiri dari senyawa fenolik yang sukar dipisahkan dan sukar mengkristal, mengendapkan protein dari larutannya dan bersenyawa dengan protein tersebut. Tanin yang terdapat pada biji alpukat merupakan golongan senyawa flavonoid yang bermanfaat sebagai astringen. Astringen dipercaya dapat mengendapkan protein selaput lendir di permukaan usus halus dan 
membentuk suatu lapisan yang melindungi usus, sehingga menghambat penyerapan glukosa dan laju peningkatan glukosa darah tidak terlalu tinggi, karena itu kadar glukosa darah menurun (Malangngi, dkk, 2012). Hasil penelitian sholhah dkk pada tahun 2013 yang telah dilakukan sebelumnya yaitu kombinasi rebusan biji alpukat dan biji papaya konsentrasi $60 \%$ dapat menurunkan kadar glukosa darah mencit dari $160 \mathrm{mg} / \mathrm{dl}$ menjadi $112,2 \mathrm{mg} / \mathrm{dl}$ dan kelompok kontrol rebusan biji alpukat mampu menurunkan kadar glukosa darah yaitu dari $134,4 \mathrm{mg} / \mathrm{dl}$ menjadi $101,6 \mathrm{mg} / \mathrm{dl}$ (Sholhah, dkk, 2013). Sediaan biji alpukat (Persea americana Mill.) dalam bentuk tea bag apakah bisa menurunkan kadar gula darah belum pernah dilaporkan dan sedian biji alpukat (Persea americana Mill.) dalam bentuk tea bag belum diuji kemampuan dalam menurunkan gula darah.

\section{METODELOGI PENELITIAN}

Penelitian ini merupakan penelitian PraEkperimen yaitu penelitiaan yang bertujuan untuk mengatahui suatu gejala atau pengaruh yang timbul sebagai akibat dari adanya perlakuan. Rancangan penelitian yang digunakan adalah One group Pretest-posttest. Populasi dan sampel dalam penelitian ini adalah tikus putih ( $R$. norvegicus) yang hiperglikemik. Besar sampel atau unit eksprimen yang digunakan pada penelitian menggunakan ketentuan WHO, dimana jumlah minimal sampel perkelompok adalah 5 ekor dengan faktor koreksi $10 \%$, sehingga hewan coba yang digunakan berjumlah 6 ekor untuk mengantisipasi drop out (Rahmawati, dkk, 2015). Tehnik pegambilan sampel yang digunakan dalam penelitiaan ini adalah Non Random Purposive Sampling. Hewan coba yang digunakan dalam penelitian ini adalah berdasarkan kriteria inklusi : Tikus putih jantan strain wistar, Tidak ada kelainan anatomik yang tampak, Umur 2-4 bulan, Berat badan tikus putih 150-300 gram dan telah diaklimatisasi selama 7 hari terhadap air, makanan, udara, dan kondisi laboratorium. Kriteria eksklusi : sakit atau stress, terdapat cacat morfologi pada hewan coba yang diperiksa dan memiliki kelainan anotomik yang tampak. Variabel bebas penelitian ini adalah sediaan biji alpukat (P. americana Mill.) dalam bentuk tea bag. Variabel terikat adalah kadar gula darah tikup putih ( $R$. norvegicus) yang hiperglikemik. Alat : Pisau, Petridish, Blender, Neraca Analitik, Tea bag, Gelas ukur, Beaker glass, Cawan petri, Jarum 1cc, Gunting, Easy touch GCU + stik. Bahan : Biji alpukat, Aloksan dan Alkohol 70\%. Adapun metode kerja penelitian ini adalah sebagai berikut :

Persiapan dan Aklimatisasi Hewan Coba Tikus Putih ( $R$. norvegicus). Aklimatisasi hewan coba dilakukan selama 1 minggu dengan menggunakan air, makanan, dan kondisi laboratorium. Penelitian ini menggunakan tikus putih $(R$. norvegicus) strain wistar jantan dengan berat badan tikus 150-300 gram, usia 2-4 bulan, dengan kondisi fisik sehat, karena beberapa alasan yaitu mudah dipelihara dan dikembangbiakkan, mudah diambil darahnya dan fisiologisnya diperkiran identik dengan manusia (Kusumawati, 2004).

\section{Pembuatan Kondisi Hiperglikemik}

Hewan coba tikus putih ( $R$. norvegicus) masing-masing ditimbang berat badan untuk memenuhi syarat, lalu periksa kadar gula darah menggunakan stick glukosa GCU. Kemudian berikan induksi aloksan dengan dosis 120 $\mathrm{mg} / \mathrm{KgBB}$ secara intraperitoneal. Setelah 72 jam atau 3 hari perika kembali kadar gula darah hewan yang telah diinduksi aloksan sebelumnya. kadar gula darah tikus normal adalah 50$135 \mathrm{mg} / \mathrm{dl}$ dan dikatakan hiperglikemik apabila kadar gula darah tikus >135 mg/dl (Rahman, 2014). 


\section{Cara Pemeriksaan Kadar Gula Darah Pada Hewan Coba Tikus Putih $(R$. norvegicus)}

Sebelum pengambilan darah, ekor tikus dibersihkan dahulu dengan alkohol $70 \%$. Selanjutnya, diambil darah melalui ujung ekor, dimana ujung ekor tikus ditoreh dengan menggunakan pisau bedah kecil hingga membentuk sayatan yang dalam dan di ukur kadar gula darah dengan alat glukometer easy touch $G C U$. Caranya dengan setetes darah tikus yang berasal dari ujung ekor diteteskan pada stik glukosa yang telah dimasukkan dalam glukometer. Sebelumnya pada glukometer dilakukan penyesuaian kode yang tertera pada kemasan stik glukosa. Setelah darah diteteskan pada stik, ditunggu selama 10 detik untuk menunggu hasil pembacaan konsentrasi glukosa darah pada glukometer. Nilai yang tertera pada glukometer merupakan nilai konsentrasi glukosa darah dengan satuan $\mathrm{mg} / \mathrm{dL}$ (Rosdiani, 2013).

\section{Pembuatan Sediaan Biji Alpukat dalam Bentuk Tea bag}

Biji alpukat yang telah diperoleh dikumpulkan, dikupas dan diambil bagian bijinya setelah itu dicuci bersih. Setelah itu dikeringkan dengan cara diangin-anginkan tanpa terkena sinar matahari langsung. Biji alpukat dipotong tipis-tipis setelah itu dikeringkan menggunakan oven pada suhu $45^{\circ} \mathrm{C}$ selama $2 \times 24$ jam, kemudian dihaluskan dengan menggunakan blender. Hasil blender berupa serbuk dimasukkan kedalam tea bag, dimana berat serbuk yang dimasukkan ke dalam masingmasing tea bag sebanyak 2 gram.

\section{Perlakuan Terhadap Hewan Coba Tikus Putih ( $R$. norvegicus) Strain Wistar}

Hewan coba tikus putih Putih ( $R$. norvegicus) strain wistar masing-masing ditimbang berat badannya, jika sudah memuhi syarat, tikus putih yang sudah hiperglikemik diberi air dari sediaan biji alpukat dalam bentuk tea bag 1 kali sehari selama 7 hari dengan cara ditimbang sebanyak 2 gram bubuk biji alpukat yang sudah dikemas dalam tea bag dan tea bag dicelupkan selama 3 menit kedalam $100 \mathrm{ml}$ aquadest yang telah didihkan, volume larutan dari hasil sediaan biji alpukat dalam bentuk tea bag diberikan secara sonde sebanyak 2 $\mathrm{ml}$ yang merupakan volume yang boleh diberikan berdasarkan pada volume normal lambung tikus yaitu 3-5 ml. Jika volume larutan melebihi volume lambung, dapat berakibat dilatasi lambung secara akut yang dapat menyebabkan robeknya saluran cerna tikus.

\section{Pengukuran Kadar Gula Darah Setelah Pemberian Sediaan Biji Alpukat dalam Bentuk Tea bag}

Tikus putih ( $R$. norvegicus) yang sudah diberikan sediaan biji alpukat dalam bentuk tea bag 1 kali sehari selama 7 hari berturut-turut, kemudian ditimbang berat badan masing-masing. Diberikan tanda pada masing-masing tikus. Dilakukan pengambilan darah tikus putih melalui ekor dengan cara memotong ekor tikus secara aseptik. Setelah itu dilakukan pengukuran kadar gula darah sewaktu dengan menggunakan alat Easy touch GCU.

\section{Penggunaan Alat Easy touch GCU Metode Stik.}

Disesuaikan kode angka yang terdapat pada botol stik dengan kode yang terdapat pada code card. Dimasukan code card pada bagian atas sisi belakang alat. Alat akan hidup secara otomatis kemudian dimasukan terlebih dahulu stik standar, kemudian stik glukosa darah dan akan terlihat kode stik gula darah yang sesuai dengan kode yang tertera pada code card. Dilakukan pengambilan darah kapiler pada hewan coba kemudian darah diserap dengan ujung stik. Setelah inkubasi sepuluh detik, hasil akan muncul pada layar sebagai kadar gula darah. 


\section{Analisis Data}

Data yang diperoleh dari hasil pengukuran kadar gula darah sebelum dan setelah perlakuan dilakukan analisa wilcoxon test pada tingkat kepercayaan $95 \%(\mathrm{p} \alpha 0,05)$.

\section{HASIL PENELITIAN}

Kadar Gula Darah Tikus Putih Sebelum dan setelah hiperglikemik. Data yang didapatkan dari hasil pengukuran kadar gula darah tikus putih ( $R$. norvegicus) sebelum hiperglikemik dan setelah hiperglikemik. Serta data Selanjutnya sebelum dan setelah perlakuan dengan memberikan sediaan biji alpukat $(P$. americana Mill.) dalam bentuk tea bag selama 7 hari dapat dilihat pada tabel 1 dan 2 sebagai berikut :

\section{Tabel 1}

Data Hasil Pemeriksaan Kadar Gula Darah Tikus Putih Sebelum dan setelah hiperglikemik

\begin{tabular}{|c|c|c|c|c|}
\hline \multirow[t]{7}{*}{ No } & \multicolumn{4}{|c|}{ Kadar Gula Darah (mg/dL) } \\
\hline & $\begin{array}{c}\text { Sebelum } \\
\text { Hiperglikemik }\end{array}$ & $\begin{array}{c}\text { Setelah } \\
\text { Hiperglikemik }\end{array}$ & selisih & $\begin{array}{c}\text { Persentase } \\
(\%)\end{array}$ \\
\hline & 79 & 174 & 95 & 54,60 \\
\hline & 93 & 147 & 54 & 36,73 \\
\hline & 96 & 177 & 81 & 45,76 \\
\hline & 80 & 499 & 419 & 83,96 \\
\hline & 84 & 135 & 51 & 37,77 \\
\hline Rerata & 86,4 & 226,4 & 14 & 61,84 \\
\hline \multicolumn{3}{|c|}{$\begin{array}{l}\text { Tabel } 1 \text { menunjukkan bahwa rerata } \\
\text { hasil pemeriksaan kadar gula darah } \\
\text { pada tikus putih }(R \text {. norvegicus }) \\
\text { strain wistar sebelum hiperglikemik } \\
\text { adalah } 86,4 \mathrm{mg} / \mathrm{dL} \text { dan rerata hasil } \\
\text { pemeriksaan kadar gula darah } \\
\text { hewan coba tikus putih }(R . \\
\text { norvegicus }) \text { strain wistar setelah }\end{array}$} & \multicolumn{2}{|c|}{$\begin{array}{l}\text { hiperglikemik adalah } 226,4 \mathrm{mg} / \mathrm{dL} \text {. } \\
\text { Hal ini menunjukan bahwa } \\
\text { terjadinya peningkatan kadar gula } \\
\text { darah pada hewan coba tikus putih } \\
(R \text {. norvegicus) strain wistar setelah } \\
\text { induksi aloksan sebesar } 140 \mathrm{mg} / \mathrm{dl} \text {, } \\
\text { dengan persentase } 61,84 \%\end{array}$} \\
\hline
\end{tabular}

Tabel 2

Data Hasil Pemeriksaan Kadar Gula Darah Tikus Putih Sebelum dan Setelah Perlakuan Kadar Gula Darah (mg/dL)

\begin{tabular}{|c|c|c|c|c|}
\hline & \multicolumn{4}{|c|}{ Kadar Gula Darah (mg/dL) } \\
\hline & $\begin{array}{c}\text { Sebelum Pemberiaan } \\
\text { Sediaan Biji Alpukat } \\
\text { Dalam Bentuk Tea } \\
\text { Bag }\end{array}$ & $\begin{array}{c}\text { Setelah Pemberiaan } \\
\text { Sediaan Biji } \\
\text { Alpukat Dalam } \\
\text { Bentuk Tea Bag }\end{array}$ & Selisih & $\begin{array}{c}\text { Persentase } \\
\quad(\%)\end{array}$ \\
\hline & 174 & 110 & 64 & 36,78 \\
\hline & 147 & 95 & 52 & 29,89 \\
\hline & 177 & 113 & 64 & 36,15 \\
\hline & 499 & 357 & 142 & 28,45 \\
\hline & 135 & 95 & 40 & 29,62 \\
\hline Rerata & 226,4 & 154 & 72,4 & 31,98 \\
\hline
\end{tabular}


pemeriksaan kadar kadar gula darah hewan coba tikus putih $(R$. norvegicus) strain wistar setelah perlakuan adalah $154 \mathrm{mg} / \mathrm{dL}$. Hal ini menunjukan bahwa terjadinya penurunan kadar gula darah pada hewan coba tikus putih $(R$. norvegicus) strain wistar sebesar $72,4 \mathrm{mg} / \mathrm{dL}$ dengan persentase penurunan sebesar $31,98 \%$.
HASIL UJI STATISTIKUji Wilcoxon test bertujuan untuk mengatahui apakah ada pengaruh pemberiaan sediaan biji biji alpukat dalam bentuk tea bag terhadap penurunan kadar gula darah tikus putih ( $R$. norvegicus) strain wistar yang hiperglikemik. Uji Wilcoxon test dilakukan dengan bantuaan komputer program SPSS pada tingkat kepercayaan 95\% $(\alpha 0,05)$. Hasil uji Wilcoxon test dapat dilihat pada tabel 3 sebagai berikut

Tabel 3

Hasil uji Wilcoxon Test dari data hasil pemeriksaan kadar gula darah hewan coba tikus putih ( $R$. norvegicus) strain wistar

\begin{tabular}{lc}
\hline \multicolumn{2}{c}{ Test Statistics $^{\mathbf{a}}$} \\
\hline Gula Darah (Post) - Gula Darah (Pre) \\
\hline Asymp. Sig. (2-tailed) & $-2.032^{\mathrm{b}}$ \\
\hline As & .042
\end{tabular}

a. Wilcoxon Signed Ranks Test

b. Based on positive ranks.

Tabel 3 menunjukkan hasil bahwa asymp sig= 0,042 $<0,05$ maka $\mathrm{H}_{\mathrm{o}}$ ditolak dan $\mathrm{H}_{\mathrm{a}}$ diterima, artinya adanya pengaruh sebelum dan setelah pemberian sediaan biji alpukat $(P$. americana Mill.) dalam bentuk tea bag terhadap kadar gula darah tikus putih (R. norvegicus) strain wistar yang hiperglikemik.

\section{PEMBAHASAN}

Rerata kadar gulah darah sewaktu hewan coba tikus putih ( $R$. norvegicus) sebelum hiperglimik adalah $86,4 \mathrm{mg} / \mathrm{dL}$, sedangkan rerata kadar gula darah pada hewan coba tikus putih ( $R$. norvegicus) setelah hiperglikemik adalah 226,4 $\mathrm{mg} / \mathrm{dL}$. Hal ini menunjukan bahwa terjadi peningkatan kadar gula darah pada hewan coba tikus putih $(R$. norvegicus) strain wistar sebesar 140 mg/dL. Peningkatan kadar gula darah setelah induksi aloksan karena aloksan secara selektif merusak sel dari pulau langerhans dalam pankreas yang mensekresi hormon insulin. Aloksan merupakan bahan kimia yang digunakan untuk menginduksi diabetes pada binatang percobaan. Pemberian aloksan adalah cara yang cepat untuk menghasilkan kondisi hiperglikemik pada binatang percobaan (Irdalisa, dkk, 2015). Aloksan dapat menyebabkan diabetes melitus tergantung insulin pada binatang tersebut (aloksan diabetes) dengan karakteristik mirip dengan diabetes mjelitus tipe 1 pada manusia. Aloksan bersifat toksik selektif terhadap sel beta pankreas yang memproduksi insulin karena terakumulasinya aloksan secara khusus melalui transporter glukosa yaitu GLUT2, Karena rusaknya sel beta pankreas maka insulin tidak terbentuk sehingga kadar glukosa darah meningkat. Hal ini seperti proses yang terjadi pada diabetes melitus tipe 1 pada manusia. Pemeriksaan kadar gula darah sebelum dan setelah pemberian sediaan 
biji alpukat ( $P$. americana Mill.) selam 7 hari. Rerata kadar gula darah hewan coba tikus putih ( $R$. norvegicus) strain wistar sebelum pemberiaan sediaan biji alpukat adalah 226,4 mg/dL sedangkan rerata kadar gula darah hewan coba tikus putih ( $R$. norvegicus) strain wistar setelah pemberiaan sediaan biji alpukat adalah $154 \mathrm{mg} / \mathrm{dL}$. Hal ini menunjukkan bahwa sediaan biji alpukat dalam bentuk tea bag mampu menurunkan kadar gula darah dengan rerata selisih penurunanya adalah 72,4 $\mathrm{mg} / \mathrm{dL}$. Penurunan gula darah ini disebabkan karena kandungan tanin dan flavonoid yang terkandung dalam biji alpukat. Efek tanin yang terkandung dalam biji alpukat ( $P$. americana Mill.) dalam mengendapkan atau mempresipitasikan protein selaput lendir di permukaan usus halus dan membentuk suatu lapisan yang melindungi usus, terbukti dapat menghambat absorbsi glukosa sehingga laju peningkatan glukosa darah tidak terlalu tinggi. Tingginya kadar tanin sebagai antioksidan akan mampu menurunkan kadar glukosa darah melalui perbaikan fungsi pankreas (dengan cara regenerasi sel) untuk meningkatkan produksi insulin. Jika produksi insulin lebih banyak, maka akan mempercepat masuknya glukosa dari darah ke dalam hati dan otot, sebagian glukosa diubah menjadi glikogen (Sholhah, dkk, 2013). flavonoid yaitu zat yang mampu meregenerasi sel beta pankreas dan membantu merangsang sekresi insulin (Dheer, et al, 2010). Jumlah kenaikan kadar yang berbeda-beda antara hewan coba disebabkan karena kondisi fisiologis yang berbeda dan jumlah penurunan kadar gula darah yang bervariasi setelah perlakuan dapat disebabkan oleh oleh faktor endogen masing-masing tikus putih yang bersifat individual dan banyak dipengaruhi oleh beberapa faktor non fisik dan lingkungan. Hasil penelitian sebelumnya menunjukkan pemberiaan Infusa biji alpukat ( $P$. americana Mill.) menurunkan kadar gula darah tikus strain wistar yang diberi beban glukosa (Anggraeni, 2006). Penggunaan rebusan biji alpukat ( $P$. americana Mill.) dapat menurunkan gula darah mencit, rebusan biji alpukat ( $P$. americana Mill.) terbukti menurunkan kadar gula darah mencit sampai 32,8 mg/dL (Sholhah, dkk, 2013). Hasil uji menggunakan Wilcoxon test menunjukkan hasil yang signitifikan yaitu $p=0,042<\alpha=0,05$ sehingga jawaban dari hipotesis yaitu Ho ditolak dan Ha diterima yang berarti adanya pengaruh pemberian sediaan biji alpukat ( $P$. americana Mill.) dalam bentuk tea bag terhadap kadar gula darah tikus putih ( $R$. norvegicus) strain wistar yang hiperglikemik.

\section{KESIMPULAN}

Rerata kadar gula darah tikus putih $(R$. norvegicus) strain wistar yang hiperglikemik sebelum diberikan sediaan biji alpukat ( $P$. americana Mill.) dalam bentuk tea bag yaitu 226,4 $\mathrm{mg} / \mathrm{dL}$. Rerata kadar gula darah tikus putih ( $R$. norvegicus) strain wistar yang hiperglikemik setelah diberikan sediaan biji alpukat (P. americana Mill.) dalam bentuk tea bag $154 \mathrm{mg} / \mathrm{dL}$. Pemberian sediaan biji alpukat $(P$. americana Mill.) dalam bentuk tea bag dapat menurunkan kadar gula darah tikus putih ( $R$. norvegicus) strain wistar yang hiperglikemik.

\section{SARAN}

Perlu dilakukan penelitiaan lebih lanjut tentang kemungkinan adanya pengaruh makanan yang dikonsumsi hewan coba selama penelitian terhadap kadar gula darah hewan coba itu sendiri dapat penelitian mengenai pengukuran kadar gula darah menggunakan metode spektrophotometri sebagai pembanding menggunakan jenis sediaan biji alpukat dalam bentuk lain.

\section{DAFTAR PUSTAKA}

Anggraeni, A. D. (2006). Pengaruh Pemberian Infusa Biji Alpukat (Persea americana Mill.) Terhadap Kadar Glukosa Darah 
Tikus Wistar yang Diberi Beban Glukosa. In Karya Tulis Ilmiah. Universitas Diponegoro Semarang.Brahmachari, G. (2011). Bio-flavonoids with promising anti- diabetic potentials: A critical survey. jJrnal Research Signpost, 661(2), 187212.

Dheer, \& Batnagar P. (2010). A study of the Antidiabetic Activity of Barleria prionitis Linn. Indian Journal of Pharmacology, Vol 42 (2), 70-72.

Erawantini, F., Farlinda, S., \& Wulandari, R. A. (2017). Perancangan Aplikasi Penetu Faktor RiSiko Diabetes Melitus Tipe 2 Secara Dini Berbasis Web. Jurnal Kesehatan, 5(1), 32-36.

Irdalisa, Safrida, Khairil, Abdullah, \& Sabri, M. (2015). Profil Kadar Glukosa Darah Pada Tikus Setelah Penyuntikan Aloksan Sebagai Hewan Model Hiperglikemik. Jurnal EduBio Tropika, 3(April), 25-28.

Iyos, R. N., \& Astuti, P. D. (2013). Pengaruh Ekstrak Daun Sirsak (Annona muricata L.) terhadap Penurunan Kadar Glukosa Darah. Majority, 6(2), 144-148.

Kusumawati, D. (2004). Bersahabat dengan Hewan Coba. Yogyakarta: Gadjah Mada University Press.

Lestari, D. D., \& Purwanto, D. S. (2013). Gambaran Kadar Glukosa Darah Puasa Pada Mahasiswa Angkatan 2011 Fakultas Kedokteran Universitas Sam Ratulangi Dengan Indeks Massatubuh. Jurnal EBiomedik (eBM), 1(2), 991-992.

Malangngi, L. P., Sangi, M. S., \& Paendong, J. J. E. (2012). Penentuan Kandungan Tanin dan Uji Aktivitas Antioksidan Ekstrak Biji Buah Alpukat (Persea americana Mill.). Jurnal Mipa Unsrat Online, 1(1), 5-10.

Marlinda, M., Sangia, M. S., \& Wuntu, A. D. (2016). Analisis Senyawa Metabolit Sekunder dan Uji Toksisitas Ekstrak Etanol Biji Buah Alpukat (Persea americana Mill.). Jurnal Mipa Unsarat Online, 1 (1)(February), 24-28.

Rahman, S. (2014). Efek Hipoglikemik Kombinasi Infusa Biji Alpukat (Persea americana Mill.) dan Biji Pepaya (Carica papaya L Var. Bangkok) Asal Kab . Pinrang Pada Tikus (Rattus norvegicus) Jantan. Bionature, 15, 111-116.

Rahmawati, \& Aryu Candra, K. (2015). Pengaruh Pemberiaan Seduhan Daun Kelor
(Moringa Oleifera Lamk) Terhadap Kadar Asam Urat Tikus Putih (Rattus norvegicus). Journal of Nutrition College, 4, 903-910.

Rosdiani, N. F. (2013). Uji efek antihiperglikemik ekstrak etil asetat lumut hati. In Skripsi. Universitas Islam Negeri Syarif Hidayatullah Jakarta.

Setiawan, R. (2010). Pengaruh Pemberian Ekstrak Kelopak Bunga Rosela (Hibiscus sabdariffa L) Terhadap Penurunan Kadar Gula Darah Tikus Putih (Rattus norvegicus) Yang Diinduksi Aloksan.

Sholhah, A. F., \& Qomariyah, N. (2013). Pengaruh Pemberian Kombinasi Rebusan Biji Alpukat (Persea americana) dan Biji Pepaya (Carica papaya ) terhadap Kadar Glukosa Darah Mencit. Jurnal LenteraBio, 2(3), 191-195.

Suarsana, I. N., Widyastuti, S., \& Priosoeryanto, B. P. (2012). Ketersediaan Hayati Isoflavon dalam Plasma dan Pengaruhnya Terhadap Nilai Biokimia Darah pada Tikus Hiperglikemia. Jurnal Veteiner, 13(1), 8691.

Sujana, I. N. (2009). Pola Konsumsi Makanan Tradisional Bali sebagai Faktor Risiko Diabetes Melitus Tipe 2 di Tabanan. Jurnal Skala Husada, 6(1), 75-81.

Susanto, M. (2014). Efek Kulit Manggis (Garcinia mangostana L.) Yang Diekstraksi Etanol $40 \quad \%$ Terhadap Aktivitas AST dan ALT Pada Tikus Putih (Rattus norvegicus) Jantan. In Skripsi. Fakultas Kedokteran Universitas Lampung.

Yuriska, A. (2009). Efek Aloksan Terhadap Kadar Glukosa Darah Tikus Wistar. In Karya Tulis Ilmiah. Universitas Diponegoro Semarang. 